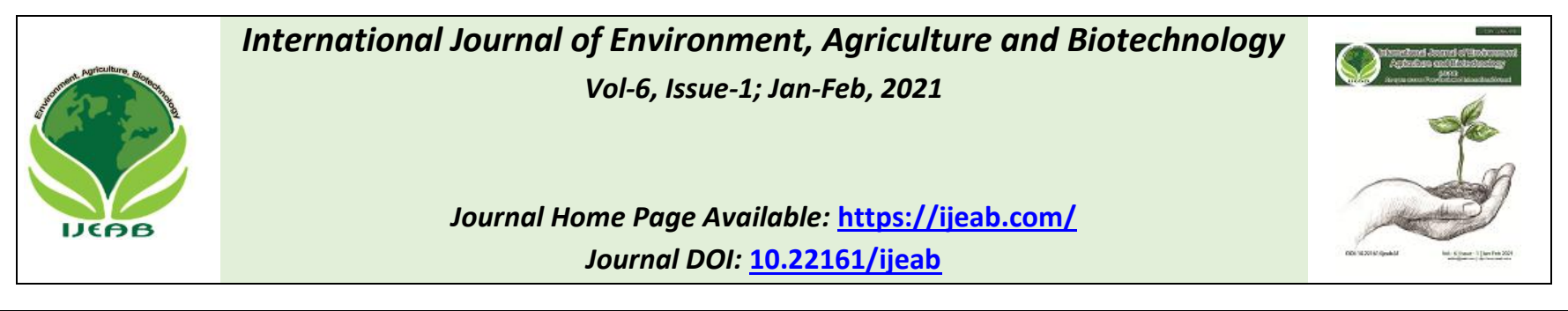

\title{
Profile of Progesteron, Estrogen and Pregnancy Level of Pasundan Cattle after Estrus Synchronization with Prostaglandin and Releasing Gonadothropin Hormone
}

\author{
Euis Nia Setiawati ${ }^{1 *}$, Mas Yedi Sumaryadi ${ }^{2}$, and Vony Armelia ${ }^{2}$ \\ ${ }^{1}$ Animal Health Training Center, Cinagara Bogor, Indonesia \\ ${ }^{2}$ Faculty of Animal Science, JenderalSoedirman University, Purwokerto, Indonesia \\ *Corresponding Author
}

Received: 10 Nov 2020; Received in revised form: 09 Jan 2021; Accepted: 18 Jan 2021; Available online: 28 Jan 2021

(C)2021 The Author(s). Published by Infogain Publication. This is an open access article under the CC BY license

(https://creativecommons.org/licenses/by/4.0/).

\begin{abstract}
Twenty Pasundan cows were used in this study in order to determine the concentration of the hormones estrogen, progesterone, and the level of pregnancy. The cows were randomly divided into two groups of 10 each. The first group was synchronized with a prostaglandin double injection (Lutalyse TM, Upjohn, Kalmozoo USA, containing $25 \mathrm{mg}$ of Dinoprost Tromethamin) at a dose of $5 \mathrm{ml} / \mathrm{head}$ intramuscularly 2 (two) times with an interval of 11 days. The second group was injected with prostaglandins (PGF2 $\alpha)$ at a dose of 5 $\mathrm{ml} / \mathrm{head}$ intramuscularly 2 (two) times with an interval of 11 days, but on the 9th day they were injected with gonadotropin realizing hormone (Fertagyl, Intervet Animal Health UK Ltd, Cambridge; which contained 100 $\mu g$ Gonadorelin which is synthetic GnRH)), Cows in heat are artificially inseminated twice with an interval of 6 hours. The variables observed were concentrations of estrogen and progesterone during estrus and 2 months of pregnancy, service preconception, and calving rate. The data were processed with analysis of variance and descriptive. The results showed that cows that were injected with PGF2 $\alpha+G n R H$, had an average plasma concentration of the hormone progesterone $2.68 \pm 0.19 \mathrm{ng} / \mathrm{ml}$ and $26.65 \pm 2.09 \mathrm{pg} / \mathrm{ml}$ estrogen, service preconception 1.0, a calving rate $90 \%$ higher than those injected with $\alpha$ PGF2 including progesterone. $2.68 \pm$ $0.19 \mathrm{ng} / \mathrm{ml}$ and estrogen $26.65 \pm 2.09 \mathrm{pg} / \mathrm{ml}$, service preconception 1.2 and calving rate $90 \%$. The results of the analysis of variance showed that the plasma concentrations of progesterone and estrogen when the cows were 60 days pregnant when they were injected with the PGF2 $\alpha+G n R H$ combination had a very significant effect $(P<0.01)$ higher than the control $(P G F 2 \alpha)$. It was concluded that the progesterone, estrogen profile, pregnancy rate results from estrus synchronization using a combination of PGF2 $\alpha$ and HnRH higher than single PGF $2 \alpha$.
\end{abstract}

Keywords-Progesterone, Estrogen, Pregnancy Level, Pasundan Cattle.

\section{INTRODUCTION}

Pasundan cattle are livestock germplasm from West Java which has an important role in meeting food needs and welfare for society and the environment. In this case, the cow germplasm is the basic capital for the development of the livestock sub-sector because it can be engineered to form superior livestock seeds that are suitable for tropical conditions and socially and culturally acceptable to the community. The problem faced by many Pasundan cattle breeders is that the reproductive function of Pasundan heifers is not optimal, which is marked by late puberty and silent heat which causes the pregnancy rate to be not optimal. Many 
factors affect the individual reproductive performance of Pasundan cattle which are often difficult to identify. The real conditions in the field are even in optimum conditions, the reproduction process of Pasundan cows can be imperfect due to the contribution of various influencing factors during the pregnancy process until the child is born safely. Understanding the relationship of various factors in influencing livestock fertility is of course essential to optimize the reproductive performance of each Pasundan female cow and livestock business. The development of the estrus synchronicity technique is one way to improve reproductive performance and productivity in Pasundan heifers. Synchronization of estrus is carried out by manipulating the viability of the corpus luteum (CL) using prostaglandin hormone preparations (PGF2 $\alpha$ ), or a combination of PGF2 $\alpha$ and GnRH aimed at stimulating the development of dominant follicles resulting in ovulation.

Pregnancy is a series of processes of immunological and endocrinological changes to produce a child in the womb from fertilization to normal birth. In line with increasing gestational age, several conceptual hormones, especially estrogen and progesterone, experience an increase (Frastantie et al., 2019), which of course will be followed by changes in the mother's metabolism to support the success of the reproductive process (Pemayun, 2014; Geisert and Schmitt, 2002). In other words, the reproductive success of the parent to produce children in one reproductive cycle is influenced by various factors from the zygote, embryo, fetus to birth. Furthermore, Hafez and Hafez (2000) state that the reproduction process is closely related to the hormonal system mechanism, namely the relationship between hypothalamic-pituitary hormones, namely gonadotrophinreleasing hormone $(\mathrm{GnRH})$, follicle-stimulating hormone (FSH), and luteinizing hormone (LH). Ovarian hormones (estrogen and progesterone) and uterine hormones (prostaglandins) Ovarian hormones that have a major role in reproduction are estrogen and progesterone.

The endocrine glands involved in the pregnancy phase are the corpus luteum, follicle, placenta, hypothalamus, and pituitary. The hypothalamus and pituitary are the regulatory glands, while those that play a major role are the corpus luteum that produces progesterone, the placenta that produces progesterone and estrogen and the follicles as a producer of estrogen Progesterone $(\mathrm{P})$ is a key hormone that plays an important role in regulating the estrous cycle and maintaining a pregnancy (Gaja et al., 2013) while Estrogen is a steroid hormone produced by granulosa and theca cells from the de Graaf follicle in the ovary (Hardjopranjoto,
1995). The main function of the hormone estrogen is to stimulate sexual desire, stimulate the emergence of secondary sex characteristics, maintain the female udder system, and udder growth (Wodzicka-Tomaszewska et al., 1991).

Anderson (2003) states that during pregnancy, the growth and development of the uterus are affected by an increase in the concentration of the hormones progesterone and estrogen. Progesterone plays an important role in preparing the uterine environment for implantation and the increase in progesterone during pregnancy and plays a role in maintaining pregnancy. Progesterone, besides being produced by the corpus luteum at the beginning of pregnancy (Efendy et al, 2015). Furthermore, Ginther et al. (2010) stated that laboratory standards. Progesterone concentration in pregnant cows is maintained until near the end of pregnancy

To increase the efficiency of production and reproduction in cows, hormonal profile information is needed in the reproductive cycle (Katongole and Gombe, 2006). The results of previous studies reported that the concentrations of estrogen and progesterone had a high correlation with the number of corpus luteum in sheep (Sumaryadi and Manalu, 1995). Accurate information about reproductive hormones during pregnancy is important to study as the basic concept of the ovulation process, the corpus luteum regression cycle, the need for hormones for the manifestation of heat, pregnancy, and birth (Akusu et al., 2006). Many aspects of the reproductive appearance of Pasundan cattle have been investigated, but information on the profile of estrogen and progesterone in pregnant heifers has not been reported to date. Based on this, it is necessary to know the profile of progesterone, estrogen, and pregnancy rate in Pasundan cattle after being induced by exogenous hormones.

\section{MATERIAL AND METHOD}

The research material used was 20 Pasundan heifers aged 2.0 - 2.5 years with relatively the same weight and age, belonging to breeders who are members of the Rundayan Sawargi Group in Cibalong District, Garut Regency. All experimental cows were palpated rectally to determine their reproductive status and ensure that the cows were not pregnant. The selected animal is a healthy animal, not pregnant, and has never been a child. Experimental cows were divided into 2 groups of 10 each. The first group was synchronized with a prostaglandin double injection (Lutalyse 
TM, Upjohn, Kalmozoo USA, containing $25 \mathrm{mg}$ of Dinoprost Tromethamin), at a dose of $5 \mathrm{ml} / \mathrm{head}$ intramuscularly 2 (two) times with an interval of 11 days, to uniform physiological conditions of each cattle as control. The second group was injected with prostaglandins (PGF2 $\alpha$ ) at a dose of $5 \mathrm{ml} /$ head intramuscularly 2 (two) times with an interval of 11 days, but on the 9th day they were injected with gonadotropin realizing hormone (Fertagyl, Intervet Animal Health UK Ltd, Cambridge; which contained $100 \mu \mathrm{g}$ Gonadorelin which is synthetic $\mathrm{GnRH}$ )), at a dose of 2.5 $\mathrm{ml} /$ head intramuscularly to homogenize fertility conditions and increase fertility. Observation of estrus was carried out twice a day, namely in the morning (06.00 - 08.00 and 17.00 - 18.00) three days in a row after the last injection of PGF2 $\alpha$. Cows that are in heat are directly on IB 2 times with an interval of 6 hours after the first IB. Cows resulting from IB after 2 months do not show heat again, do rectal palpation by feeling the uterus to detect uterine enlargement that occurs during pregnancy (Jainudeen and Hafez, 2008). The variables observed were the concentration of estrogen, progesterone, service preconception, and conception rate. Blood sampling during pregnancy was done 3 (three) times during heat and at 60 days of gestation.

Blood samples for measuring the hormones estrogen and progesterone were taken from the jugular vein as much as $10 \mathrm{ml}$ using a disposable syringe containing anticoagulant, then put into a test tube and placed in a flask filled with ice. Blood was left for 30 minutes then centrifuged at $2500 \mathrm{rpm}$ for 15 minutes. The plasma formed is separated into an evendorf tube which will be used for the analysis of hormones and blood metabolites.
Estrogen. The concentration of estrogen in plasma was measured by KIT (Sigma Chemical Co., St Louis MO) using the Enzyme-Linked Immunosorbent Assay (ELISA) technique. Each Elisa plate was put in $25 \mu$ l of standard, sample, and control solution, then each was mixed with 200 $\mu \mathrm{l}$ of estradiol conjugate reagent in each well. Furthermore, incubation for 120 minutes at room temperature. The absorbance value was read on the ELISA reader after 10 minutes with a wavelength of $450 \pm 10 \mathrm{~nm}$.

Progesterone. The concentration of estrogen in plasma was measured by KIT (Sigma Chemical Co., St Louis, MO) using the Enzyme-Linked Immunosorbent Assay (ELISA) technique. On each Elisa plate, $25 \mu \mathrm{l}$ of standard, sample, and control solution were inserted, then each was mixed with $200 \mu \mathrm{l}$ of the progesterone conjugate reagent in each well. Furthermore, incubation for 120 minutes at room temperature. The absorbance value was read on an ELISA reader after 10 minutes with a wavelength of $450 \pm 10 \mathrm{~nm}$.

Data Analysis: The collected data were analyzed using analysis of variance.

\section{RESULTS AND DISCUSSION}

\section{Estrogen and Progesterone Hormone Profiles}

The concentrations of estrogen and progesterone hormones in Pasundan cattle induced by the combination of PGF2 $\alpha$ with GnRH during heat, 60 days and 150 days of pregnancy are presented in Table 1 .

Table 1. Profile of Estrogen and Progesterone Hormones in Pasundan Cows during Heat and 60 days of Pregnancy

\begin{tabular}{ccccc}
\hline Group & PGF2 $\alpha$ & PGF2 $\alpha+$ GnRH \\
\hline $\begin{array}{c}\text { Hormone } \\
\text { Concentration }\end{array}$ & Estrus & Pregnant 60 days & Estrus & Pregnant 60 days \\
\hline Estrogen $(\mathrm{pg} / \mathrm{ml})$ & $28.83 \pm 2.29$ & $22.74 \pm 2.50$ & $32.76 \pm 2,00$ & $26.43 \pm 1.32$ \\
& & & & \\
Progesteron $(\mathrm{ng} / \mathrm{ml})$ & $0.21 \pm 0.03$ & $4.71 \pm 0.19$ & $0.22 \pm 0.050$ & $4.86 \pm 0.48$
\end{tabular}

The data in Table 1 shows that the mean concentrations of conceptus hormones, both estrogen, and progesterone at 60 days of gestation in Pasundan cattle, respectively synchronized with PGF2 $\alpha+\mathrm{GnRH})$ were $26.43 \pm 1.32 \mathrm{pg} /$ $\mathrm{ml}$ and $4.86 \pm 0.48 \mathrm{ng} / \mathrm{ml}$, while in synchronization with
(PGF2 $\alpha) 22.74 \pm 2.50 \mathrm{pg} / \mathrm{ml}$ and $4.71 \pm 0.19 \mathrm{ng} / \mathrm{ml}$, respectively. This is in line with Arimbawa et al. (2012) reported that the increase and decrease in progesterone levels are in line with the development of the corpus luteum. Based on the results of the analysis of variance, it shows that the 
concentration of estrogen in the estrous phase, for treatment $(\mathrm{PGF} 2 \alpha+\mathrm{GnRH})$ has a very significant effect $(\mathrm{P}<0.01)$ higher than PGF2 $\alpha$ single. this suggests that synchronization using GnRH will increase the number of developing and mature follicles until the estrogen concentration increases and ovulation occurs. Furthermore, Nascimento et al. (2014) stated that the growth of follicles during the estrous cycle is controlled by the hormones FSH and LH, and these two hormones must be present if the growth and function (estrogen secretion) of the follicles are expected under normal conditions. The concentration of progesterone during exertion for both the PGF2 $\alpha$ treatment and the combination of PGF2 $\alpha$ and GnRH was not significantly different (P> $0.05)$, this indicates that the results of estrus synchronization using PGF $2 \alpha$ alone and the combination of PGF $2 \alpha$ and GnRH did not affect the progesterone concentration profile. GnRH injection on the 9th day before the 2nd injection of prostaglandin (PGF2 $\alpha$ ) (11th day), will stimulate the anterior pituitary to secrete gonadal hormones, namely FSH and LH. The FSH hormone can stimulate the growth of follicles and the maturation of ovarian follicles, while FSH together with $\mathrm{LH}$ induces the secretion of the hormone estrogen in large follicles. The first injection of PGF $2 \alpha$ on day 0 has a role to regress $\mathrm{CL}$, so that the level of the hormone progesterone will drop during the heat. Low levels of progesterone will have an impact on the increase in the FSH hormone which will stimulate the development of the follicles to maturity and in turn, will increase the concentration of estrogen and cause symptoms of heat in cows. This is in line with Hafez (2000) who stated that an increase in the number of follicles has a consequence of increasing levels of estrogen in the blood which will cause estrus in cows and spur ovulation due to its positive feedback effect on LH.
Based on Table 1 shows that in 60 days pregnant cows the concentration of progesterone has increased both in single PGF $2 \alpha$ treatment and in the combination of PGF $2 \alpha$ and GnRH. The results of the analysis of variance showed that the concentrations of progesterone and estrogen at the time of 60 days of pregnancy in cows that were injected with the combination of PGF $2 \alpha$ and GnRH had a very significant effect $(\mathrm{P}<0.01)$ higher than single PGF2 $\alpha$. These conditions indicate that giving GnRH to Pasundan heifers can stimulate the formation of more and more active corpus luteum thereby increasing the secretion of progesterone. This result is in line with Cerri et al. (2009), who stated that giving GnRH can increase the number of follicles, corpus luteum, and placenta and cause an increase in secretion from glands that produce a pregnancy and mammogenic hormones such as estradiol and progesterone during pregnancy. Furthermore, Siregar (2006) states that with the active corpus luteum, progesterone secretion increases. Hafez (2000), states that progesterone levels are closely related to the amount of the corpus luteum. According to Anderson (2003), during pregnancy, the growth and development of the uterus are affected by an increase in the concentration of the hormones progesterone and estradiol. Siregar (2002) further states that the concentration of progesterone during the formation period of the corpus luteum is related to the number of corpus luteum, while the concentration of progesterone in mid-pregnancy is related to the number of children to be born.

\section{Pregnancy Level (Service Perconception and Calving Rate)}

Service preconception value (S/C) will affect Conception Rate (\%). The results of the research regarding the $S / C$ and $C R$ values are presented in Table 2.

Table 2. Value of Service Perception and Conception Rate of Pasundan Heifers

\begin{tabular}{lcc}
\hline Pregnancy Level & Hormone Induction \\
& PGF2 $\alpha$ & PGF2 $\alpha+\mathrm{GnRH}$ \\
\hline Service per Conception (S/C) & 1.20 & 1.0 \\
Conception Rate $(\mathrm{CR})(\%)$ & 90.0 & 100 \\
\hline
\end{tabular}

The results of pregnancy examinations by palpation per rectally carried out on the 60th day after the first IB, showed that the calving rate for synchronizing the combination of PGF $2 \alpha$ and GnRH was $100 \%$, while for synchronization using PGF $2 \alpha$ was $90 \%$. This condition indicates that the use of GnRH can uniform ovulation in Pasundan heifers. This is in line with Efendy et al. (2015) stated that progesterone plays an important role in preparing the uterine environment for implantation and the increase in progesterone during pregnancy and plays a role in maintaining pregnancy. Progesterone, besides being produced by the corpus luteum at the beginning of pregnancy 
The value of service preconception and conception rate for Pasundan cattle that were synchronized with estrus combination of PGF2 $\alpha$ and GnRH was higher than that of PGF2 $\alpha$. This condition is in line with the picture that the concentration of estrogen and progesterone in the estrus synchronization of the combination PGF2 $\alpha$ and GnRH is higher than the synchronization with single PGF2 $\alpha$. Based on the analysis of variance, it shows that the estrous synchronization treatment (PGF2 $\alpha+\mathrm{GnRH})$ is significantly different $(p>0.05)$ higher than synchronization using single PGF $2 \alpha$ on service preconception and calving rate. The results of this study indicate that the hormones estrogen and progesterone have a strong relationship and are directly proportional to service per conception and calving rate, meaning that estrogen and progesterone affect service per conception. This is in line with the statements of Hafez (2000) and Putro (2008) which state that the GnRH hormone functions to stimulate the hypofunction of LH and FSH which work together to stimulate follicles and corpus luteum formation. This condition is thought to have lower pregnancy rates in synchronization with (PGF2 $\alpha$ ) due to early embryonal death, due to hormonal imbalances, where the progesterone required for pregnancy has not been sufficiently produced by CL. Accordance with Willard et al. (2003), who stated that one of the main causes of early embryonic death which is the cause of the low conception rate is an insufficient luteal function which is indicated by low progesterone concentrations. The results of previous research Santosa et al. (2004) reported that generally, embryo mortality can occur before 60 days after IB, before the placenta is fully formed, including embryo death at the age of 0-7 days after IB (very early embryo). Putro (2008) further states that injecting GnRH 48 hours after injection of PGF2 $\alpha$ for ovulation synchronization can improve the dynamics of follicular development, so that fertility will be better due to the influence of the GnRH hormone to stimulate follicular growth and the formation of the corpus luteum after ovulation.

The results in this study were higher than those of Chaikhun et al. (2010) who reported that NGOs that ovulated using PGF2 $\alpha$ and GnRH resulted in pregnant buffalo pregnancy $(15 \%)$ significantly lower than buffalo that had calved $(42.9 \%)$. Furthermore, the report of Sianturi et al. (2012), who used the Ovsynch method to produce pregnancy $(62.5 \%)$ in heifers. The difference in the results of the study with the previous researchers was thought to be due to the difference in the time to offer $\mathrm{GnRH}$ and the implementation of IB. In the ovsynch method, the implementation of IB was carried out 16-22 hours after the second GnRH (Ali and Fahmy, 2007), whereas in this study cows were indirect heat for 2 times with an interval of 6 hours after the first IB. On the other hand, the high pregnancy results of Pasundan cows in this study were probably due to livestock, and the condition of Pasundan cattle acceptors is quite good as indicated by the value of body conditioning scoring (BCS) 2.8 - 3.0 (for scoring 1-5).

\section{CONCLUSIONS}

Induction of the combination of PGF2 $\alpha$ and GnRH, has an average plasma concentration of the hormones progesterone $2.68 \pm 0.19 \mathrm{ng} / \mathrm{ml}$ and estrogen $26.65 \pm 2.09$ $\mathrm{pg} / \mathrm{ml}$, service preconception 1.0 , a calving rate $90 \%$ higher than those injected with single PGF2 $\alpha$ with progesterone mean of $2.68 \pm 0.19 \mathrm{ng} / \mathrm{ml}$ and estrogen $26.65 \pm 2.09 \mathrm{pg} / \mathrm{ml}$, service preconception 1.2 and calving rate $90 \%$. This success has yet to be proven by the rate at which childbirths occur.

It is recommended that the mother's nutritional adequacy during pregnancy will determine the success of giving birth so that the condition of the child is born and the mother is normal and healthy.

\section{ACKNOWLEDGEMENT}

Thank you to the breeders from the group who participated in lending Pasundan cattle in the implementation of this research. Gratitude is also conveyed to the Head of the Garut Regency Agriculture and Animal Husbandry Service and his staff who jointly assist in research activities for the application of appropriate technology to Pasundan Heifers.

\section{REFERENCES}

[1] Akusu, M.O., E. Nduka, and G.N. Egbunike (2006). Peripheral plasma levels of progesterone and oestradiol-17 $\beta$ during the reproductive cycle of West African Dwarf goats,. http://www.ilri.cgiarorg/InfoServ/ Webpub/Fulldocs/AnGenReCD/do cs/x5520B/x5520bOp.htm.

[2] ALI, A. and S. FAHMY. 2007. Ovarian dynamics and milk progesterone concentrations in cycling and non-cycling buffalo-cows (Bubalus bubalis) during Ovsynch program. Theriogenology 68: 23-28.

[3] Anderson, S.T., B.M. Bindon, M. A. Hillard, and T. O'Shea. 2003. Increased ovulation rate in Merino ewes immunonization against small syntetic peptid 
fragments of the inhibin alfa sub unit. Reproduction, Fertility and Development. 10(5):421-432.

[4] Arimbawa, I.W.P., I.G.N.B. Trilaksana, T.G.O. Pemayun. 2012. Gambaran Hormon Progesteron Sapi Bali Selama Satu Siklus Estrus. Ind. Med. Vet. 1(3):330-336

[5] Cerri RLA, Rutigliano HM, Bruno RGS, Santos JEP. 2009. Progesterone concentration, follicular development and induction of cyclic ity in dairy cows receiving intravaginal progesterone insert. Animal Reproduction Science 110: 5670.

[6] Chaikhun, T., T. Tharasanti., J. Rattanatep., F. De rensis and M. Techakumohu. 2010. Fertility of Swam Buffalo Following the Synchronization of Ovulation by the Sequential Administration GnRH and PGF2alpha Combine with FixedTimed Artificial Insemination. Theriogenology. 74:13711376

[7] Efendi, M., T. Siregar., Hamdan., Dasrul., C. Thasmi., Razali., A Sayuti dan B. Panjaitan. 2015. Angka Kebuntingan Sapi Lokal setelah diinduksi dengan Protokol Ovsynch. Jurnal Medika Veteriner. 9(2):159 -162.

[8] Frastantie, D., Muhammad Agil, dan Ligaya ITA Tumbelaka. 2019. Deteksi Kebuntingan Dini pada Sapi Perah dengan Pemeriksaan Ultrasnography (USG) dan Analisis Hormon Steroid. ActaVeterinaria Indonesia Vol 7 (2): 9 - 16

[9] Gaja AO, Al-Dahash SYA, Raju GS, Kubota C. 2013. Ultrasonic assessment of corpora lutea and plasma progesterone levels in early pregnant and non pregnant cows. Journal of advanced Biomedical and Patology Research 3(1): 19-24.

[10] Geisert, R.D. and RAM Schmitt, 2002. Early Embryonic Survival in Pig: Can it be improved ? J.Anim. Sci. 80:5485

[11] Ginther OJ, Khan FA, Hannan MA, Rodriguez MB, Pugliesi G, Beg MA. 2012. Role of LH in luteolysis and growth of the ovulatory follicle and estradiol regulation of $\mathrm{LH}$ secretion in heifers. Theriogenology 77: 1442-1452.

[12] Hafez, B. and E.S.E. Hafez. 2000.Reproduction in Farm Animals. 7th. ed. Lea and Febiger Co., Philadelphia, USA.

[13] Hardjopranjoto, S. 1995. Ilmu Kemajiran pada Ternak. Airlangga University Press. Surabaya

[14] Mann GE. 2009. Corpus luteum size and plasma progesterone concentration in cows. Animal Reproduction Science 115: 296299.

[15] Manalu W, M.Y. Sumaryadi, and N. Kusumorini, 1996. Effect of fetal number on concentrations of circulating maternal serum progesterone and estradiol of does during late pregnancy. Small Ruminant Res. 23:117-124.

[16] Nascimento AB, Souza AH, Keskin A, Sartori R, Wiltbank MC. 2014. Lack of complete regression of the Day 5 corpus luteum after one or two doses of PGF2 $\alpha$ in nonlactating Holstein cows. Theriogenology. 81: 389-395

[17] Pemayun, T.G.O. 2014. Waktu Inseminasi Buatan yang Tepat pada Sapi Bali dan Kadar Progesteron pada Sapi Bunting. Jurnal Veteriner Vol 15 (3): 425 - 430
[18] Putro, P. P. 2008. Dinamika perkembangan folikel dominan dan korpus luteum setelah sinkronisasi estrus pada Sapi Peranakan Friesian Holstein. Disertasi Pascasarjana. Universitas Gadjah Mada, Yogyakarta.

[19] Santosa, B. 2014. Penanggulangan penyakit gangguan reproduksi pada sapi potong. Balai Veteriner Bukittinggi. Bukittinggi

[20] Ulbrich S.E., K. Schulke., A.E. Groebner., H.D. Reichenbach., C. Angioni., G. Geisslinger, H.H. Meyer. 2009. Quantitative Characterization of Prostaglandins in the Uterus of Early Pregnant Cattle. Reproduction. 138:371-382

[21] Vernunft A, Weitzei JM, Viergutz T. 2013.Corpus luteum development and its morphology after aspiration of a preovulatory follicle is related to size and steroid content of the follicle in dairy cows. Veterinarni Medicina 58: 221-229.

[22] Willard, S., S. Gandy., S. Bowers., K.Graves, A. Elias and C. Whisnant. 2003. The Effects of Gnrh Administration Post Insemination on Serum Concentrations of Progesterone

[23] Wodzicka-Tomaszewska, M., I.K. Sutama, I.G. Putu, dan T.D. Chaniago 1991. Reproduksi, Tingkah Laku dan Produksi Ternak Indonesia. Penerbit Gramedia Pustaka Utama. Jakarta. 